\title{
China's Left-behind Children (Liu-shou- er-tong): Development and Challenges for the Future
}

\author{
LOO-SEE BEH
}

\begin{abstract}
This article analyses the left-behind children (LBC/Liu-shou-er-tong) phenomenon resulting from rural-urban mobility, focusing on their well-being and the problems faced. It demonstrates the current development, challenges and direction of social development as a result of this unprecedented phenomenon in Wuxi County, Chongqing. Interviews and semi-structured questionnaires were utilized in this research, which covered town and village schools, and individuals from NGOs as well as government departments. A brief concluding section draws together local government initiatives and programmes, offering a few general and interesting observations on the solutions using five models.
\end{abstract}

Keywords: left-behind children, social development and security, government, programme initiatives, reforms, China

\section{Introduction}

The phenomenon of 'left-behind children' (LBC, Liu-shou-er-tong) is an important, under-researched issue. Many studies have investigated rural to urban migration and urbanization, but research on the creation of a new phenomenon called the left-behind children is limited, although many stories of these children have been exposed in the print media. Hence, this study investigates the current phenomenon of Liu-shou-ertong in Wuxi County, Chongqing, and the local government's initiatives to solve the problem.

Like many developing countries, in China the problems of unemployment and poverty along with rural-urban migration have effects on society such as pollution, crime and congestion. However, here we are concerned more with the well-being and quality of life of these children, of being loved and valued. This should not be mistakenly compared to child poverty or poor working-class children or related conditions in children's material or educational well-being or health, which are 
measured by the three indicators of household income, access to basic educational resources and housing and living space as reported by UNICEF (2010).

Secondly, as the most populous country in the world, China is an interesting case of LBC though there are others given that European countries have raised concerns over high rates of LBC in Eastern Europe. There are about half a million LBC in the European Union and the number is increasing every year. ${ }^{1}$ According to UNICEF (2005), 14.5 per cent of the LBC were left behind by their mothers, 15 per cent by their fathers, and 6.6 per cent by both parents. In China, LBC are mainly left behind by parents who migrate within the country, usually from a small town to a big city.

Thirdly, although many researchers have explored this area of study, very few have identified the relationship between the LBC and their problems in China with regard to their social development, which may be a sensitive case for the country. Due to time and financial constraints, the field researcher limited respondents to selected schools and certain rural areas in Wuxi County, Chongqing. The northeast area has the highest number of LBC in Chongqing and Wuxi County is one of the poorest counties in China. Chongqing is the youngest municipality in southwest China, with a population of around 28.6 million according to the 2009 year-end census (Chongqing Municipal Bureau of Statistics 2010: 3-12). Out of this number, 4.4 million are LBC aged between 0-16 years old (Chongqing Women's Federation 2009). According to the survey from the Chonqing Women's Federation, in 2009 there were about 2.35 million rural LBC in Chongqing. Compared to the number of LBC (1.47 million) from the Fifth National Population Census in 2000, the number of rural LBC has increased by 0.88 million since then. ${ }^{2}$ Accordingly, rural LBC represent 53 per cent of the total population of children in this municipality; 46 per cent of the LBC live in the northeast of Chongqing, while 36 per cent live in southeast Chongqing (Chongqing Women's Federation 2009). Hence, the growth and absolute numbers of LBC strengthen the essential importance of this research.

Lastly, although the occurrence of LBC has been apparent since the late 1980s in many regions and provinces of China, there is still very little written on LBC in English, in which this is an encouraging step in embarking on more studies in this area, given the limitations of data. The current situation and policy implications may be derived for how the Chinese government could further evaluate the LBC phenomenon. 


\section{Definition of Left-behind Children}

According to international standards, every human being below the age of eighteen years is defined as a child (United Nations Office of the High Commissioner for Human Rights 1990), although different scholars have different opinions on the age range of LBCs. Duan and his colleagues defined LBC as children aged 14 or below (Duan and Zhou 2005; Duan and $\mathrm{Wu} 2009$ ). In a survey carried out by the All-China Women's Federation (ACWF) in 2007, LBC were described as children 17 years old or below (ACWF 2008). Similarly, Duan and Yang (2008) employed the same definition of LBC as the ACWF in their study in 2008. For Zhang (2010), LBC are considered to be children between 7 and 18 years old. Duan and Zhou (2006) classify them as under 18 years old. The Chongqing Women's Federation defines LBC as within the age range of 0-16 years. However, most of the scholars agree on some essential features and characteristics that the majority of LBC share, such as lack of independent ability, which means they are usually in the period of nine years of compulsory education, that is, the period covering primary school and junior secondary school years, which, according to the Ministry of Education of the People's Republic of China (2006), is age 6 or 7 to 12 or 13 for primary school and 12 or 13 to 15 or 16 for junior secondary school. Based on this categorization, this research defines LBC as children who are under 16 years old, which is consistent with the definition by the Chongqing Women's Federation survey.

The majority of scholars believe that whether one of the parents or both have migrated, the children who stay at home can be considered LBC (Duan and Zhou 2005; 2006)). However, there is a difference of opinion over the parents' migration time span. Some of the studies define LBC as children whose parents have migrated for more than three months, others suggest that it should not be less than half a year; many scholars claim that the LBC's parents should be migrant workers who have left their home and children for at least one year (Ye and Pan 2011). However, after the Fifth National Population Census in 2000, many studies on LBC agreed that the minimum period for parents' migration is six months for children to be considered as LBC (Duan and Zhou 2006). Thus, this article takes the basis of six months at the minimum. 


\section{Urbanization and the Rural-Urban Income Gap}

Since the inception of the reform programme in the late 1970s, urbanization has been one of the most important features of China's development (Dillon 2009: 61-63). In 1949 there were 132 cities in China and the urbanization rate was 10.6 per cent (Pan, Niu and Wei 2009). This rate increased to 44.9 per cent in 2007 (Fan 2008). However, according to the World Bank, the average urbanization rate in the world was 49 per cent in 1995; the urbanization rate was 75 per cent in the developed countries (China Association of Mayors 2005: 121). According to Zhang and Song (2003), the level of urbanization in China has drastically increased; the urban population of China reached 620 million and the urbanization rate was 46.6 per cent in 2009. The Annual Report on Urban Development of China estimates that the urbanization rate will reach 52 per cent in 2015, and 65 per cent in 2030 (Chinese Academy of Social Sciences Urban Development and Environmental Research Institute 2010). Although China is becoming more urbanized, the urban-rural dual structure is unlikely to change in the near future. The level of urbanization is usually measured by the share of the urban population in the total population. From this perspective, rural-urban migration is the main source of current urban growth in China (Zhang and Song 2004).

With rapid urbanization, the rural-urban income gap continues to widen. The rural-urban income gap is measured by the ratio of urban per capita disposable income to rural per capita net income (Zhang and Song 2004). According to the National Bureau of Statistics of China (NBS), the ratio of urban to rural income was 2.79:1 in 2000. It increased, however, to 3.21:1 in 2004, 3.28:1 in 2006 and 3.33:1 in 2007. The income of rural residents was less than that of urban residents as demonstrated in Figures 1 and 2 even for the most recent years, which continues to show the widening disparity. According to Zhang and Song (2003), the rural-urban income gap is the main force driving urban migration, especially for migrants from inland rural areas to coastal urban areas.

The tremendous scale of rural-to-urban migration is currently one of the most perplexing issues in China due to the dramatically increasing number of migrants within the country. China's economic growth and its rapid urbanization have provided opportunities for millions of workers to migrate from smaller towns to bigger cities. The driving forces behind China's rural-urban migration include urban-rural income disparity, surplus labour in agriculture, the modernized market economy and the government's policies on out-migration (Wang 2009). 
However, the unique dual socio-economic structure and related household registration system in China have restrained rural labourers from settling down in the cities. Therefore, many migrants have to migrate alone, leaving their families behind, resulting in a high number of LBC in China's rural areas. Rural migration brings about political and social problems in the affected areas. In 1998, the number of rural-to-urban migrants was 44.24 million; migrants totalled 150.97 million by the end of the second quarter of 2009 (NBS 2009). Migrants with children face even greater difficulties in urban areas. Initially, they were denied access to basic welfare, housing and security in the target cities as a result of the stringent household registration system and the place-based public finance system (Xiang 2007).

There were about 58 million LBC in China in 2008, of which 28 per cent were children from rural areas (ACWF 2008). The LBC rates in China are still increasing rapidly. The LBC phenomenon demonstrates the contradictions that exist between continuous, rapid development and the imperfect management system in China. As F. C. Zhao (2009) noted, the contradictions embody the conflict between unbalanced development in urban and rural areas and the incongruous economic and social developments in China. Moreover, rising income inequality has been one of the most profound social consequences during China's economic transition from an agrarian and socialist planned economy

FIGURE 1: Per capita net income of rural residents

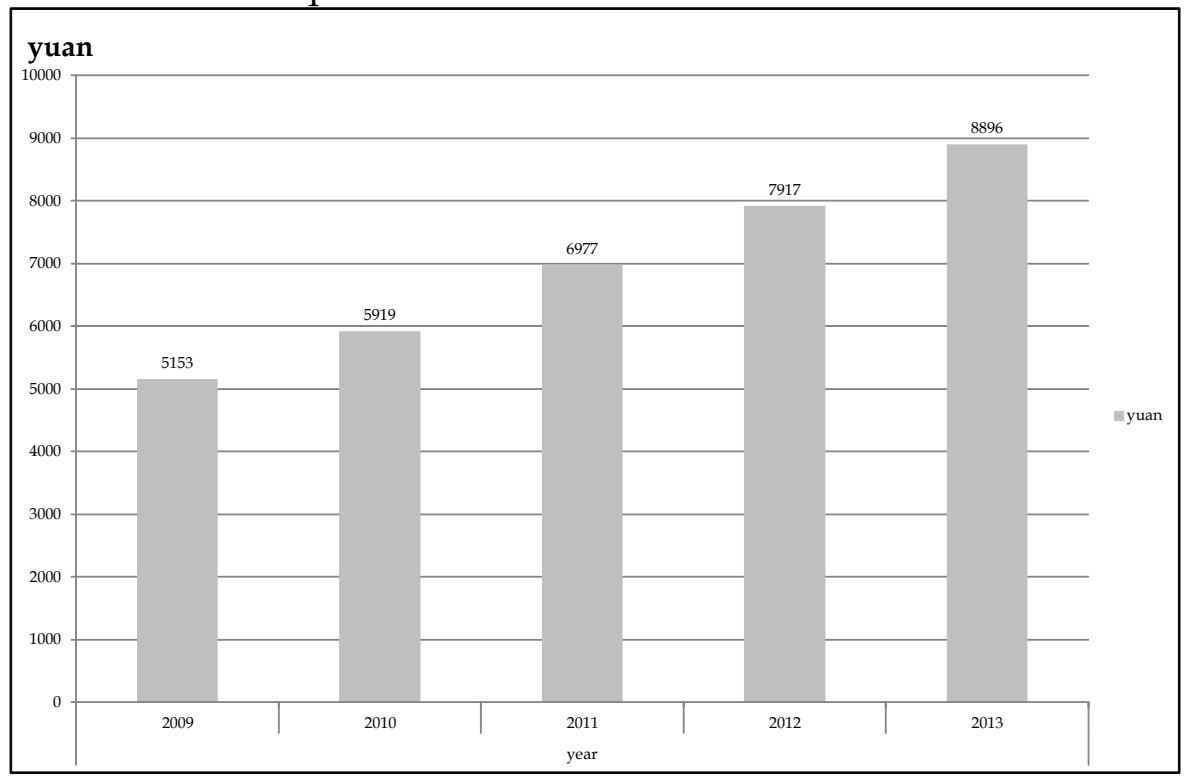

Source: National Bureau of Statistics of China (2014). 
FIGURE 2: Per capita net income of urban residents

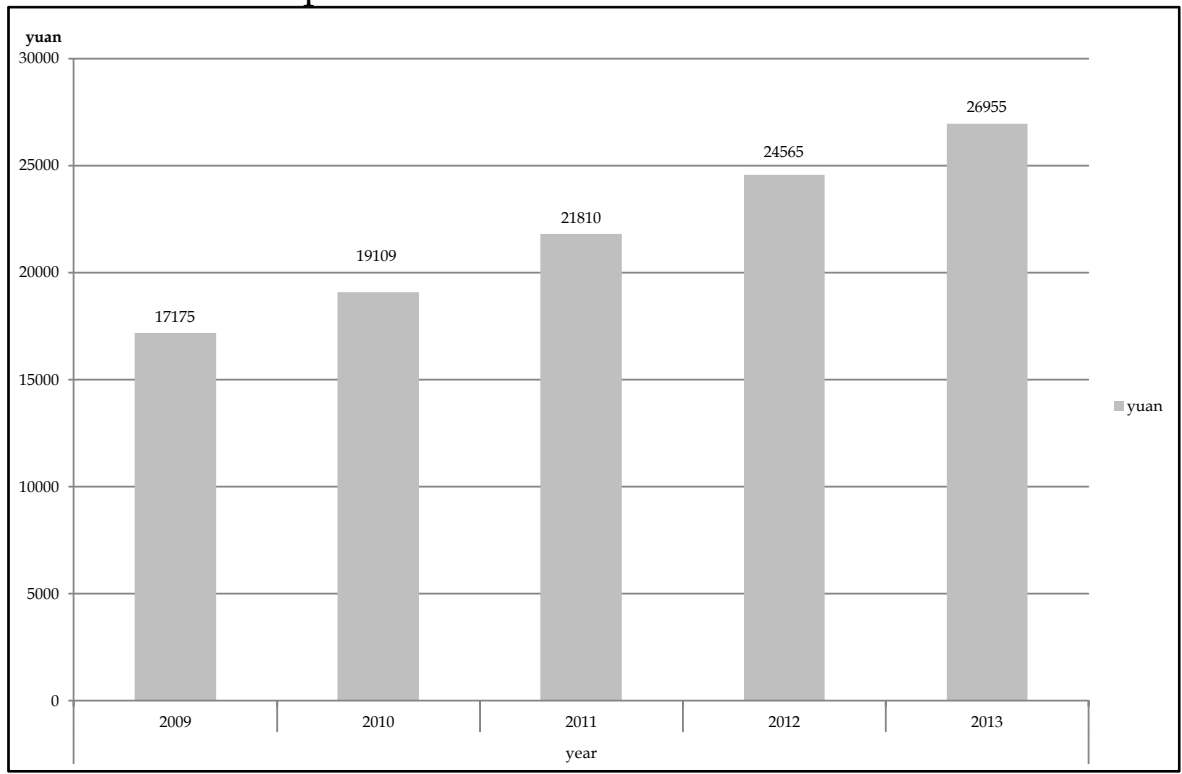

Source: National Bureau of Statistics of China (2014)

to an industrial and market-based one. Income inequality has also been accompanied by a rising trend of social and economic polarization. Figures 1 and 2 show the recent per capita net income of rural and urban areas respectively, with urban residents having a much higher income, demonstrating the wide disparity.

\section{Household Registration System - Hukou}

The household registration system, known as hukou, is an administrative measure that registers households according to their place of origin. This system records and controls internal migration and ultimately is a powerful tool of public administration by which spatial stratification is monitored. According to Richburg (2010), hukou is essentially a household registration permit, akin to an internal passport. It contains all of a household's identifying information, such as parents' names, births, deaths, marriages, divorces, moves and colleges attended. Most importantly, it identifies the city, town or village to which a person belongs. It was established in the 1950s to prevent the rural population from spontaneously moving to cities. Xiang (2007) states that under the hukou system, people born in urban areas are officially registered as residents, while those in rural areas are registered as peasants. Residents and peasants are two distinct categories of social status that entail different 
rights, and peasants cannot obtain urban hukou status unless mandated by the state. Ma (2010) observes that this designation limits a person's employment, education and social services outside of the place where they are registered. This means that having permission to enter other cities does not mean they can benefit from the same welfare as urban citizens. Rural migrant workers are not entitled to subsidized public housing, public medical insurance, government welfare services or public education beyond elementary school. The hukou system remains a formidable obstacle for the overwhelming majority of migrants who want to live with their families in the city (Xiang 2007). The majority of migrant workers in cities usually do not have long-term urban residency (or household registration status) and medical insurance. In the early days, changing a registered permanent residence was forbidden in China. According to the Ministry of Public Security (2008) in 2006, the hukou system was reformed, enabling migrants to transfer their hukou to cities. For instance, in Guangzhou City, migrants must have lived in a fixed place within the city proper (not the outskirts) for a minimum of five years, have a stable source of income, and have participated in the city's social security programme in order to be able to apply for permanent residence in the city. This effectively rules out the vast majority of internal migrant workers who are highly mobile and unlikely to have lived in the same place in the city for five years.

\section{Data Collection}

This research mainly focuses on Chongqing province, which has the highest rate (49.9 per cent) of rural LBC in China (Duan and Yang 2008). This study further covers several local government agencies such as the Education Committee of Chongqing and the Chongqing Women's Federation. Wuxi County is one of the poorest counties in Chongqing; the per capita GDP of its rural residents is US\$3,500 a year according to the 2010 census. ${ }^{3}$ Furthermore, Wuxi is one of the five counties with over 80 per cent of current and potential rural LBC in the region. ${ }^{4}$

Part of the data collected was gathered through the Internet from various websites and web pages containing LBC resources and databases, including the Chongqing Children's Library and the Chongqing Daily internal information retrieval library. For primary qualitative data, the field researcher used questionnaires and carried out semi-structured interviews. The semi-structured interviews involved school principals, teachers, volunteers, and government and non-governmental organiza- 
TABLE 1: Questionnaire Distribution and Collection

\begin{tabular}{|c|c|c|c|c|c|}
\hline $\begin{array}{l}\text { Type of } \\
\text { school }\end{array}$ & $\begin{array}{l}\text { Name of } \\
\text { school }\end{array}$ & $\begin{array}{l}\text { No. of stu- } \\
\text { dent ques- } \\
\text { tionnaires } \\
\text { distributed }\end{array}$ & $\begin{array}{l}\text { No. of stu- } \\
\text { dent } \\
\text { question- } \\
\text { naires col- } \\
\text { lected }\end{array}$ & $\begin{array}{l}\text { No. of } \\
\text { teacher } \\
\text { question- } \\
\text { naires } \\
\text { distributed } \\
\end{array}$ & $\begin{array}{l}\text { No. of } \\
\text { teacher ques- } \\
\text { tionnaires } \\
\text { collected }\end{array}$ \\
\hline \multirow{3}{*}{$\begin{array}{l}\text { Town } \\
\text { school }\end{array}$} & $\begin{array}{l}\text { Gulu } \\
\text { Primary } \\
\text { School } \\
\end{array}$ & 90 & 79 & 15 & 9 \\
\hline & $\begin{array}{l}\text { Huanyan } \\
\text { Primary } \\
\text { School }\end{array}$ & 70 & 40 & 15 & 7 \\
\hline & \begin{tabular}{|l|} 
Xiabao \\
Primary \\
School \\
\end{tabular} & 100 & 82 & 15 & 7 \\
\hline $\begin{array}{l}\text { Village } \\
\text { school }\end{array}$ & $\begin{array}{l}\text { Houping } \\
\text { Primary } \\
\text { School }\end{array}$ & 30 & 11 & 10 & 4 \\
\hline \multirow{2}{*}{$\begin{array}{l}\text { Town } \\
\text { school }\end{array}$} & $\begin{array}{l}\text { Shanghuan } \\
\text { Secondary } \\
\text { School }\end{array}$ & 65 & 40 & 15 & 9 \\
\hline & \begin{tabular}{|l|} 
Bailu \\
Secondary \\
School \\
\end{tabular} & 65 & 44 & 15 & 11 \\
\hline Total & & 420 & 295 & 85 & 49 \\
\hline
\end{tabular}

tion (NGO) staff. The questionnaires covered students and teachers in the selected schools. Tables 1 and 2 show the field research distribution and collection of data.

There are 247 schools in Wuxi County, including 19 junior secondary schools with 1,823 secondary students and 218 primary schools with 2,666 primary students (Chongqing Municipal Bureau of Statistics 2011). From among 216 primary schools, only three town schools and one village school agreed to participate in the survey questionnaires. There are no junior secondary school in the villages, thus, the field researcher was obliged to visit three junior secondary schools in different towns. The respondents are Grade 5 and Grade 6 students in primary school and Grade 1 and Grade 2 students in junior secondary school. A total of 505 questionnaires (420 students and 85 teachers) were distributed, 344 (295 student questionnaires and 49 teacher questionnaires) were returned. Of those, 295 were complete and valid for data extraction. 
TABLE 2: Interview Respondents of the Study

\begin{tabular}{|c|c|c|}
\hline \multirow{5}{*}{$\begin{array}{l}\text { Government } \\
\text { departments }\end{array}$} & Chongqing & Wuxi County \\
\hline & $\begin{array}{l}\text { Office Director of Youth } \\
\text { Council }\end{array}$ & $\begin{array}{l}\text { Vice-minister of Propaganda } \\
\text { Department }\end{array}$ \\
\hline & $\begin{array}{l}\text { Officer of the Next Generation } \\
\text { Working Committee }\end{array}$ & $\begin{array}{l}\text { Office Director of Education } \\
\text { Committee }\end{array}$ \\
\hline & $\begin{array}{l}\text { Officer of the Women's } \\
\text { Federation }\end{array}$ & $\begin{array}{l}\text { Chair of the Next Generation } \\
\text { Working Committee }\end{array}$ \\
\hline & $\begin{array}{l}\text { Office director of Youth } \\
\text { Home-Member of Youth } \\
\text { Service Centre }\end{array}$ & $\begin{array}{l}\text { Chair of the Women's } \\
\text { Federation }\end{array}$ \\
\hline \multirow{6}{*}{ NGOs } & \begin{tabular}{|l|} 
Office of Green Leaves \\
Volunteers
\end{tabular} & \multirow{6}{*}{$\begin{array}{l}\text { The founder of the 'Lehe home/ } \\
\text { Global Village' }\end{array}$} \\
\hline & $\begin{array}{l}\text { Office of Big Hands Link Small } \\
\text { Hands Volunteer Association }\end{array}$ & \\
\hline & $\begin{array}{l}\text { Office director of YuZhou } \\
\text { Volunteer Service Centre }\end{array}$ & \\
\hline & $\begin{array}{l}\text { Chair of Mountain City } \\
\text { Volunteer Service }\end{array}$ & \\
\hline & $\begin{array}{l}\text { Chair of New Sunshine } \\
\text { Volunteer Alliance }\end{array}$ & \\
\hline & $\begin{array}{l}\text { Chair of Chongqing Youth } \\
\text { Student Volunteers Association }\end{array}$ & \\
\hline \multirow{3}{*}{ Individuals } & \multirow{3}{*}{ The officers of the above NGOs } & $\begin{array}{l}\text { Surrogate caregivers/sur- } \\
\text { rogate mothers from the } \\
\text { Yangqiao village and Daping } \\
\text { village }\end{array}$ \\
\hline & & LBC from 6 schools \\
\hline & & $\begin{array}{l}\text { Teachers or principals from } \\
\text { Xiabao and Daping Primary } \\
\text { School }\end{array}$ \\
\hline
\end{tabular}

\section{Current Situation}

According to the Chongqing Women's Federation's survey, in 2009 there were 2.35 million 0-16 year old rural LBC, compared to the Fifth National Population Census in 2000, an increase of 0.88 million (60 per cent) (Chongqing Women's Federation 2009). In Chongqing, 28 per cent of rural LBC have to walk half an hour to go to school, and 15 per cent walk for two hours. Around 700,000 rural LBC spend one hour on the way to school and back (Chongqing Women's Federation 2009).

The majority of LBC are primary school students. In 2008, rural LBC were 42.2 per cent of students in primary school, and over 40 per cent of students in secondary school in Chongqing. Both were the highest 
rate in China (Ministry of Education Development and Planning 2009). According to the Chongqing Women's Federation, 18 per cent of LBC are 0-6 years old, 55 per cent are 6-12 years old, and 27 per cent are 12-16 years old. Males are 53 per cent of the total LBC (Chongqing Women's Federation 2009). A survey of six counties shows that the majority of rural LBC are studying in primary school; few LBC have had formal pre-school education. Most of the rural LBC up to 6 years of age have not received any standard pre-school education. This is especially true in poor areas. For example, only 30 per cent of the 3-6 year old LBC have received preschool education in Wushan and Wuxi counties (Wu 2010).

LBC have diverse family structures. Wu (2010) indicates that the majority of LBC are cared for by single parents and grandparents. Fifty per cent of LBC are left behind with their mother, 32 per cent stay with their grandparents, 15 per cent are living with their father, and 3 per cent are cared for by others. According to Fu and Liu (2008), 2.54 per cent of LBC stay alone, 34.65 per cent of LBC have no parents at home, and 23.4 per cent of LBC stay with their grandparents. According to Fu and Liu (2008), 79 per cent of LBC have been taken care of by their grand parents in Chongqing. The Chongqing Women's Federation summarized that among 2.35 million rural LBC, both parents have left home for 1.3 million; that is to say, 55 per cent of rural LBC have no parents at home, and 32 per cent of LBC live with their grandparents. ${ }^{5}$ Wang (2009) noticed that most of LBC lack parents at home and 95 per cent of LBC contact their parents via phone once a week. Moreover, LBC are unevenly distributed in Chongqing. There are nine counties each with 100,000 rural LBC. LBC are over 80 per cent of the total rural children in five counties (Chongqing Women's Federation 2009; Wu 2010). Tables 3 through 6 summarize the current findings of LBC in Wuxi County.

Among the 295 LBC respondents, 212 are students (113 males and 99 females) from primary schools and 83 (46 males and 37 females) are students from junior secondary schools. Given the definition of LBC defined in this research, the respondents were from 6-16 years of age, thus the survey only covered the fifth and sixth grades in the primary schools, and the first and second grades of the junior secondary schools.

Among these children, 70 LBC were 8-10 years old, 195 were 11-12 years old, and 30 were from 13-15 years old. In addition, 97.2 per cent of the LBC from the primary schools were between 8 and 12 years old, while 98.8 per cent were from the junior secondary schools, aged 11-15. This shows that the schooling age rule of the compulsory education policy has been effectively implemented. Among 49 teacher question- 
Loo-See Beh

TABLE 3: Family Structure of LBC in Wuxi County (2011)

\begin{tabular}{|l|l|l|l|l|l|l|}
\hline & \multirow{2}{*}{$\begin{array}{l}\text { No. of } \\
\text { students }\end{array}$} & $\begin{array}{l}\text { LBC with both } \\
\text { parents as } \\
\text { migrants }\end{array}$ & \multicolumn{3}{|c|}{ LBC's guardians } \\
\cline { 3 - 7 } & & Number & \% & $\begin{array}{l}\text { Grand- } \\
\text { parents }\end{array}$ & $\begin{array}{l}\text { Other } \\
\text { relatives }\end{array}$ & Others \\
\hline Primary school & 33,354 & 10,165 & 30.48 & 8,132 & 1,708 & 325 \\
\hline Junior secondary & & & & & & \\
school & 21,306 & 6,148 & 28.86 & 4,918 & 982 & 248 \\
\hline Total & & & & & & \\
\hline
\end{tabular}

Source: Compiled by field researcher from Education Committee of Wuxi County

TABLE 4: Migrated Family Member Based on Different Types of Schools

\begin{tabular}{|l|c|c|c|c|}
\hline \multirow{4}{*}{ Type of school } & \multicolumn{3}{|c|}{ Migrated family member } & \multirow{2}{*}{ Total } \\
\cline { 2 - 5 } & \multicolumn{3}{|c|}{} & \\
& Father & Mother & Both parents & \\
\hline \multirow{3}{*}{ Primary school } & 38 & 21 & 153 & 212 \\
\cline { 2 - 5 } & $12.9 \%$ & $7.1 \%$ & $51.9 \%$ & $71.9 \%$ \\
\hline \multirow{2}{*}{ High school } & 18 & 1 & 64 & 83 \\
\cline { 2 - 5 } & $6.1 \%$ & $0.3 \%$ & $21.7 \%$ & $28.1 \%$ \\
\hline \multirow{2}{*}{ Total } & 56 & 22 & 217 & 295 \\
\cline { 2 - 5 } & $19.0 \%$ & $7.5 \%$ & $73.6 \%$ & $100.0 \%$ \\
\hline
\end{tabular}

Source: Compiled by field researcher from Education Committee of Wuxi County 
naires, 29 respondents were from the primary schools, including 4 primary village school teachers. Another 20 teachers were from junior secondary schools.

Based on the student questionnaires, Figure 3 indicates that 46.8 per cent of the fathers and 40 per cent of the mothers have been away from home for more than one year. Only 5.1 per cent of the LBC's fathers have left home for less than 6 months, and 2.4 per cent of the LBC's mothers work away from their hometown for up to 6 months. The study also shows that 62 per cent of the fathers work outside Chongqing. Similarly, the majority of mothers (66.4 per cent) migrate from Chongqing; only 19 per cent of the fathers work in Chongqing, and 12 per cent of the fathers work and live in Wuxi County.

FIGURE 3: Period of Separation from Parents
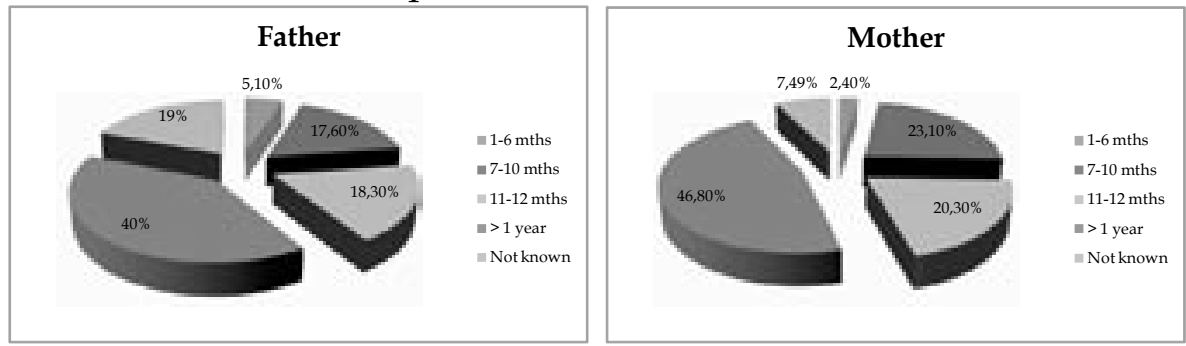

As illustrated in Tables 5 and 6, in terms of the relationship between the LBC and their guardians, 36.3 per cent of the LBC believe their grandparents are the most important persons for them, 31.2 per cent think that their father is the most important figure in their lives; 24.1 per cent chose their mothers as the most important person. These numbers indicate that the grandparents take over the role of parents in terms of LBC's affection. On the other hand, it also shows that 41.7 per cent of

TABLE 5: Most Important Person(s) for LBC

\begin{tabular}{|l|c|c|}
\hline & Number Frequency & $\%$ \\
\hline Grandparents & 107 & 36.3 \\
\hline Father & 92 & 31.2 \\
\hline Mother & 71 & 24.1 \\
\hline Teacher & 3 & 1.0 \\
\hline Friends / Classmates & 1 & 0.3 \\
\hline Relatives & 12 & 4.1 \\
\hline Sisters or brothers & 9 & 3.1 \\
\hline Total & 295 & 100.0 \\
\hline
\end{tabular}


the $L B C$ received aid mostly from their grandparents, while just over 15 per cent of the LBC have been accounted for by their parents. The result reveals that $\mathrm{LBC}$ have closer relationships with their grandparents than their parents in addition to the roles played by their relatives.

TABLE 6: Person(s) Helping LBC the Most

\begin{tabular}{|l|c|c|}
\hline & Number Frequency & $\%$ \\
\hline Grandparents & 123 & 41.7 \\
\hline Father & 55 & 18.6 \\
\hline Mother & 43 & 14.6 \\
\hline Teachers & 20 & 6.8 \\
\hline Relatives & 29 & 9.8 \\
\hline Sisters / Brothers & 25 & 8.5 \\
\hline Total & 295 & 100.0 \\
\hline
\end{tabular}

Since the household registration system reforms started in Chongqing in 2011, some rural residents have changed to citizenship in cities. This initiative of Chongqing's government has fundamentally helped solve the LBC issue. However, 71.9 per cent of the LBC hope their parents will come back home. Only 11.9 per cent of the LBC wish to follow their parents to the city. As our interviews indicate, most of the LBC are not comfortable with city life and are afraid of being discriminated against because they are from a rural area. Some of them are satisfied with rural life. On the other hand, 14.2 per cent of the LBC do not care whether their parents come back home; while 2 per cent of the LBC do not wish their parents to come back at all as they felt they have lost their love for them. These findings showed that some of the LBC have not had any relationship with their parents.

\section{Challenges for the Country}

In 2008, the ACWF reported that, based on the 2005 by-census, there were about 58 million rural LBC; the majority of LBC are boys (53.7 per cent), reflecting the overall gender ratio in rural China of 118:100. There were higher proportions of girls in Beijing, Shanghai, Inner Mongolia, Ningxia and Xinjiang (Duan and Zhou 2005).

The majority of LBC are distributed in the west and middle of China. In 2002, 86.23 per cent of migrant workers went to eastern China, out of which 77.4 per cent of them came from the middle and west of China 
(Fan et al. 2010). The ACWF indicates that 52 per cent of total rural LBC population are in Sichuan, Anhui, Henan, Guandong, Huan, and Jianxi provinces (ACWF 2008; Duan and Zhou 2005). The LBC's distribution density in rural areas is higher than in urban areas. Rural LBC are 20.2 per cent of all rural children, while urban LBC represent 5.5 per cent of all urban children. In other words, in the rural areas, there is one LBC for every five children, while in urban areas it is one in every 18 children (Duan and $\mathrm{Wu} 2009$ ).

According to the NBS (2011), there are two generations of rural migrant workers. Rural migrant workers generally were born from 1960 to 1970, and their children are the first generation of LBC. The new generation of rural migrant workers were born after 1980. They are the main rural migrant workers today (Wang and $\mathrm{Hu}$ 2011). The report by the NBS (2011) also shows many of the new generation of rural migrants work after junior secondary school. The average age of the new generation of rural migrant workers who were born after 1990 is 17.2 years. Moreover, according to Liu and Zhou (2008), many junior high school students dropped out of school and started working away from their villages. Some of the challenges found in this study are summarized below.

\section{Risks for the Next Generation's Development}

Many of these LBC face serious mental and physical problems during their growing stage, which affect their character and values as they become adults. Hence, looking into the near future, this also can affect the quality of human resources in the next generation. According to Ding (2009), most LBC have very poor scores in their studies, high rates of repetition of the same class and a high level of drop-outs. They also tend to dislike studying, are usually undisciplined and have no ambitions or goals in their lives. According to Duan and Zhou (2006), the drop-out rates of LBC are usually higher in secondary school. Apart from that, many LBC develop health problems in the critical growing stage and are reportedly weak in their anthropometrics, such as height and weight. There is also a significantly higher proportion of LBC who suffer from psychological and behavioural problems. A survey conducted by Yeoh and Lam (2006) in Jichun County with 250 junior high school students whose parents had left them for at least half a year, revealed that 16.6 per cent of these students felt abandoned, 12.3 per cent of them had problems expressing difficulties or obtaining help, and 6.5 per cent of them felt anguished about being left behind. 


\section{Risks to Society's Security}

As supported by Chan's research (2009), LBC have a higher risk of being involved as victims of accidents and crimes compared to children with both parents, since they lack supervision from parents and have no one to guide them on the proper way of life. Furthermore, it is reported that LBC suffer a higher risk of abduction and abuse (ACWF 2008). As noted by an NGO, the China Youth Research Centre, 40 per cent of the juveniles in reform centres in 2006 were LBC (though this data may not be authenticated officially).

According to the state news agency Xinhua, sexual assaults on leftbehind girls in rural areas account for the majority of reported assaults. For instance, in Huazhou in Guangdong province, 94 per cent of cases involve left-behind children. Generally, as they lack the attentive care and supervision of parents and are often entrusted to relatives and less devoted guardians, even security in schools is compromised where they could be raped by the teachers. A recent report by $\mathrm{CNN}^{6}$ noted that in China around 30 million children under 18 have no parent at home and 2 million fend for themselves with no adult guardian. In fact, there are an estimated 61 million LBC growing up without one or both of their parents.

\section{Risk to China's Sustainable Development}

The LBC issue also has a negative impact on China's sustainable development. First, it may extend the economic gap between rural and urban areas. The LBC usually follow their parents to the city as the new generation of immigrants. One third of 15-17 year old rural LBC began to work in urban areas after graduating from secondary school (ACWF 2008). Therefore, fewer farmers work on the land in rural areas. This means that many villages in China have become deserted, with only elderly people and younger children left behind. Second, the LBC phenomenon has increased the economic gap between east and west China. For the eastern part of China, being on the receiving end of migration has allowed economic development with cheaper labour. On the other hand, for the western part of China, the difficulty in finding labourers has contributed to its slower economic growth; this has led to another problem as most families in western China live on lower incomes, with only some basic needs fulfilled. As a result, this is widening the gap between the east and west of China. The second and third generation migrants to the city are more willing to live permanently in the city rather than returning to the rural area. As most LBC who work in the city have little education, they are unable to earn a higher income, 
which increases the gap between the rich and poor in cities, aggravating China's inequality problem.

\section{Loss of Ethical and Moral Values}

LBC's moral problems affect the continuation of Chinese traditions. Due to long separation periods, parents and children are unable to spend time together. Therefore, compared to children who have both parents at home, the LBC tend to have more disciplinary problems. They do not have strong relationships with their parents. There is no sign of adequate affection between such children and their parents. As a result, this affects LBC's personality development as they are less able to distinguish right from wrong, having no role model to look up to in their lives, especially during the growing stage. As mentioned, too, by Zhang (2010), most LBC would have the common values distorted as a result of not having parents with them as many LBC are spoilt, unappreciative and selfish. Parents try to compensate their lack of love and affection by buying lots of toys and giving money to their children. This only worsens the situation between parents and children, encouraging LBC to develop consumerist and materialistic attitudes. It may be difficult to say what the direct consequences will be when the LBC come of age but it is believed that a loss of affection, ethics and moral values will have detrimental effects on the next generation of these LBC and future social development, as they may have different impacts psychologically on the persons involved, given the physical and psychological assaults suffered.

Contrary to the argument that the LBC phenomenon cannot be compared to other peasant studies, it is important to note the difference of the effect of poverty and migration. According to the labour surplus model, rural-urban migration is a natural and output-gain process whereby the urban areas benefit from the in-migration. The surplus labour from the rural sector provides manpower for urban industrial growth. Unlike neoclassic theory, the new economics of labour migration considers household fragmentation through temporary or circular migration, rather than an individual decision to the detriment of those left behind (Hall 2010). No doubt, migration has a positive contribution to household income and rural development. On the other hand, structuralism states that migration is not only a consequence but also a cause of depopulation and underdevelopment in the original home regions, contributing to depopulation and scarcity of skilled labour, among other negative impacts. World-systems and Marxist theories consistently consider labour migration as a natural response to the 
penetration of weaker societies by the economic and political institutions of the developed world and that migration is a move to capitalism. However, the migrants who have difficulties getting jobs in cities and urban areas suffer differently from the LBC, as they are predominantly migrant adults as compared to those left-behind children below 16 years of age who are mostly defenseless as they face more challenges and risks involved beyond their control as noted in this discussion.

\section{Government and Social Initiatives}

The imperfect system of rapid development has resulted in inequality among migrants and permanent residents of the urban areas in terms of household registration, education and welfare among others in their quest for better employment opportunities. According to the Department of Services and Management of Migrant Population of the National Population and Family Planning Commission of the Floating Population Management Division (2010), rural labour migration is estimated to reach up to 60 per cent of the total work force. By 2050, migration will reach about 350 million in the labour force. By that time, even the new generation of LBC will also join the migration statistics due to the unbalanced economic development and basic public services in urban and rural areas. Cities will continue to attract migrants. The rising number of migrants will impose additional burdens on social management, thus aggravating inequality.

Chongqing is one of the first cities in China to initiate solutions to the problems encountered by LBC. The Chongqing Model is aimed at analysing and solving problems faced by LBC, and it can also be applied to analysis and solution of LBC problems across China. Since migrants do not have sufficient money or energy to take care of their children, lack of parental supervision and the inability to provide emotional support to their children is a common problem faced by migrant families or parents. Moreover, due to unstable employment conditions, migrants have to constantly hunt for new opportunities. Without basic economic security, migrants to urban areas have to be particularly cautious about bringing family members with them (Xiang 2007).

The comprehensive reform of urban and rural areas was first implemented in Chongqing for a trial run. This initiative aims to push the development of Chongqing through a project called 'big city leads a big countryside'. In 2008, the Chongqing municipal government published their opinion on ways to strengthen support of rural LBC. This was the 
beginning of exploration of possible solutions, which involved daily life care, education, security, medical care, social aid and support.

In June 2010, the Chongqing Municipal Party Committee held the seventh session of the third congress. This congress decided to launch a project aimed at caring for 1.3 million rural LBC. Since implementation, this project has added 400 boarding schools, and 'stand-in parents' / surrogate caregivers, including LBC care centres. 'Stand-in parents'/surrogate caregivers are volunteers, who mainly serve the practical and emotional needs of left-behind children. The LBC care centres are built in schools or villages with facilities including a library, reading room, science and technology activity room, etc. to monitor the LBC's education, life activities and hobbies. The Education Department, the Women's Federation, Commission of Communist Youth League, Committee for the Well-being of Youth and the Civilization Department are mainly in charge of implementing these policies.

Concurrently, the Chongqing government is focusing on nine areas of care for the rural LBC. They involve promoting education, financial subsidies, school construction, an egg and milk project, special training, family links, psychological guidance, helping and community care. The education promotion involves several government departments such as the Public Security Bureau, the Education Bureau, the Women's Federation, etc. The rural LBC's education is one of the assessments of counties' education implementation in Chongqing. Financial subsidies mainly operate through the Abolition of Tuition and Miscellaneous Fees project for rural LBC in compulsory education. The school construction refers to rural boarding school and urban migrant children's schools. Further, the egg and milk project aims to improve the LBC's nutrition by providing free eggs and milk for students in primary schools and junior secondary schools. The special training aims to have 95 per cent rural LBC entering high school.

The family link programme includes the construction of the family chat room and family hotline. These measures are based on information network infrastructure in rural schools. The purpose of this programme is to strengthen communication between LBC and their parents by providing free calls. The psychological guidance programme offers psychological counseling to rural LBC. The 'helping' activity pairs volunteers and LBC. Government helps volunteers to build friendships with LBC and help LBC through a one-to-one relationship in education, daily life, mental health, etc. The community care plan expects the community to support LBC. The first week of October has been set as the time for 
publicity on the care of rural LBC. Thus this policy initiative attempts to mobilize everyone in the society to support rural LBC's education, health and living environment.

In September 2010, a circular from the Administrative Office of the Chongqing Municipal Committee and General Office of the People's Government of Chongqing Municipality on the Action Plan established six plans. The first is to construct rural boarding schools and kindergartens, innovate training models, develop community, promote LBC's nutrition and health, and protect LBC's rights. Specifically, it planned to complete 2,000 rural boarding schools and 1,000 rural kindergartens promoting an enrollment rate in rural kindergartens rate up to 75 per cent.

Second, to install 2,000 family video chat rooms and 5,000 family hotlines. Thefamily video chat room measure is a more modern and technical way of communication between LBC and their migrant parents. It provides computers, internet and computer labs in rural schools. Third, the community development plan aims to build 100 rural LBC custodial centres and mobilize the society to implement the stand-in parents, brothers and sisters' / surrogate caregivers' roles where appropriate. The affectionate brothers/sisters programme is the extension of the 'helping' programme. It recruits university students to contact LBC regularly, be friends with LBC and listen to their problems, help LBC's in their schooling and mental health. By 2012, the construction of 100 LBC homes and 1,000 LBC's guardian classes were completed. The LBC's guardian class offers training to LBC guardians to help guardians provide better parenting and supervision.

In addition, in terms of LBC's health, free lunches to rural poor nonresident pupils, free eggs and milk to all students, free medical checkups and 100 per cent safe drinking water are offered in rural schools. In Chongqing, given that 28 per cent of rural $\operatorname{LBC}(700,000)$ have to walk half an hour to go to school, and 15 per cent walk two hours, many LBC have no time to return home for lunch. Hence, the lunch programme provides meals to students in school canteens. Finally, the school campus guards' team and campus police were set up to defend the LBC's security.

In 2012, the Chongqing government decided to implement the six projects setting up additional boarding schools and LBC care centres. According to $\mathrm{Wu}$, the vice-mayor of Chongqing, there will be 75 per cent standard rural boarding schools, 95 per cent of rural schools will implement 'egg and milk' and lunch programmes, 120 rural kindergarten centres, 109 rural children's centres, 200 social practice education stations and 200 LBC homes will be constructed, and 19,000 surrogate caregivers 
and 30,000 university volunteers will be recruited by 2015 .

Furthermore, given that the household registration system is the fundamental obstacle for LBC, in July/August 2010, the Chongqing government reformed the rural-urban household registration system to a limited extent. This reform allows the transfer of rural registered permanent residence to urban registered permanent residence with the condition that farmers must work in the urban area for at least five years or invest in a business in the city, and pay tax totalling 100,000 yuan or at least 50,000 yuan in one year. At the same time, the farmer is required to work three years or invest 50,000 and pay taxes 50,000 in three years or 20,000 in one year in the county. However, this reform has some advantages and disadvantages.

The first advantage is that the farmers are allowed to retain their lands in rural areas for the first three years after they have become urban citizens. The second advantage is these farmers could retain the right to use the rural forest land, as outlined in the agricultural policy before they give up their land. And finally, farmers have the right to enjoy employment, social security, housing, education and health care when they register for urban permanent residence. However, this reform requires farmers to sacrifice their land for urban household registration in the longer term.

In addition, according to the Education Committee of Chongqing, the restrictions on requirements of migrant children's education were loosened. In 2008, the Chongqing government issued a circular on the abolition of tuition and miscellaneous fees for students in compulsory education in urban areas. It eliminates the school fees for migrant children. However, in practice, this was only implemented in certain schools. On the other hand, there are still some prerequisite requirements for migrant children prior to joining an urban school, which include the criteria that the rural migrant worker has a stable job and a place to live (either on a rental or ownership basis).

Based on interviews and observations during the research, the activities on LBC in Chongqing could be categorized into five models: sympathy model, education model, society support model, communication support model and local government initiative model.

In brief, the sympathy model refers to individuals, groups or organizations that provide materials and spiritual aid to LBC. The sympathy model being the umbrella model, as I would call it, resonates well with all other subsequent models.

For instance, since 2009, Chongqing Electric Power Corporation has invested in $12 \mathrm{Yu}$-electric Chunmiao Houses, which provide reading 
rooms and telephone rooms to rural LBC. According to the director of the NGO, Youth Service Center Lu, the 'Flow Children's Palace' project, which started in 2010, brought volunteer teachers to rural areas providing free training in vocal music, dancing, calligraphy, painting, etc. This project benefits at least 50,000 LBC every year.

Further, the Children Learning Partner channel of China Telecom, provided academic teaching and services to 234,430 children in 2011. The 'Care for the LBC's Healthy Growth' activity spent over 10 million yuan to provide free medical check-ups in 2011 in Chongqing. This served over 1 million rural LBC from 3 to 16 years of age. Among them, 230,000 LBC were of pre-school age, 870,000 were in the compulsory education period.

According to Zhou, the vice-director of the Propaganda Department, and also the director of the Department of Civilization of Chongqing, the lottery centre of Chongqing donated 500,000 yuan to establish the 'Loving Lottery-Finance Aid', constructing four schools and one LBC home, which improved the living environment for more than 4,700 poor children. In recent years, especially during Children's Day, Chinese New Year and other festivals, LBC receive many gifts, materials, and sympathy from government departments, NGOs and individuals. In February 2012, the Propaganda Department, Education Committee, Department of Civilization, Women's Federation, Next Generation Working Committee, along with the Electricity Firm of Chongqing arranged the LBC's summer camp.

Since late 2009, the Chongqing Municipal Party Committee and the Education Scientific Research Institute together carried out the 'LBC training model experiment of Chongqing'. The Shizhu Lengshui primary school and the Fengdu Beijing Youth primary school were the pioneers in this project. This experiment was funded by the Dingxin International Group Corporation. Subscribing to the requirements of the Laboratory Municipal Party Committee, the Municipal Science Institute created the 'China left-behind children nets', where book series written by teachers were supported.

In the society support model, training for teachers and surrogate caregivers was provided for by NGOs and government institutions. The first group of surrogate mothers was in Nanchuan district of Chongqing in 2005; it has since expanded all over Chongqing. In 2007, the Next Generation Working Committee issued 'stand-in parents' certificates to more than 2,000 individuals; 100,000 were issued by 2012 . 
There was notable implementation of the community support model in Wuxi County. This action saw the construction of close to 2,000 'Lehe Homes' in rural areas to provide a happy and peaceful community for LBC with a community care environment. In Chongqing, the 'Shi Chuan Town LBC Fund' was the first NGO specifically intended for LBC. This NGO was established in 2011 with 150 volunteers to look after 1,000 LBC. The Chongqing Youth Student Volunteers Association was registered in 2007 and has implemented many activities to help LBC, such as donating materials and money, providing psychological care activities and holding summer camps since 2008. However, not all the NGOs are registered. The researcher interviewed six NGOs that work for the welfare of LBC in Chongqing: The Chongqing Youth Student Volunteers Association (重 庆青年助学基金会), Mountain City Volunteers (山城义工), YuZhou Volunteers (渝州义工), Green Leaves Volunteers (绿叶义工), New Sunshine Volunteers (新阳光义工) and the Big Hands Link Small Hands Volunteer Association of Chongqing (重庆大手拉小手志 愿者协 会). Only the first of these is a registered NGO, the other five, which are not registered, are known as grassroots NGOs. Usually the registered NGOs are government-organized or have some policy links with government departments. For example, the Chongqing Youth Student Volunteers Association is led by the WangZhou County government. NGOs in Chongqing mainly implement the sympathy model and society support model to help LBC. In our interviews, we found that NGOs chiefly offer financial aid to LBC in addition to providing other connected services.

Lastly, in the local government initiative model, the Committee and Village Party Branch and NGOs together implement the villager's assembly, and voluntary surrogate mothers/caregivers via formal application. These volunteers link with LBC, in terms of health and safety, and in their homework. A platform is also created in providing training and developing rural tourism via 'global village public centres' such as 'Lehe Homes' where the products of trainers and volunteers are exhibited and sold. Given the social commitment from the NGOs, corporate commitments and the government, the policy is working to uplift many of these LBC.

To build a better future for the young society, some of the local government's measures and initiatives are in evidence in addition to the support of citizens. The existence of LBC is a reality that may not be easily accepted by many who may consider it a sensitive national issue. There is tremendous economic prosperity in China, but this is a dark side of the country that many do not want exposed. This means 
two Chinas are emerging that may significantly understate the gap of incomes, welfare and economic development, which are increasingly polarized. The rural areas, which usually concentrate on farming, lack the resources and experience for farming in the future. If there is policy failure, then there must be new policy or a recasting of existing policy and more needs to be done to elevate the LBC's lives and the effectiveness of the current initiatives. In terms of policy reformulation, the government has sought to invest in rural areas and the benefits of growth seem promising. The limited hukou reform could be further examined and experimented with to loosen restrictions to tackle the urban-rural divide and to see the need for the children to move with their parents to cities and to render services for the left-behind.

\section{Concluding Remarks}

As urbanization continues in China, the migration of rural labourers from villages and smaller towns to bigger urban areas is inevitable. However, this migration seems to be a necessity for China to be able to continue its social and economic growth and development. Hence, it is inevitable that the number of LBC will increase in the near future. Therefore, it is vital to analyse and find possible solutions relating to the problems faced by LBC, mainly in their education, health and security. It is also important to note that this problem should be handled before it becomes a bigger problem, hindering the social and economic growth and development of China. One of the main outcomes of this study is that its findings can be used to raise awareness of the LBC in China's society and government. Furthermore, this research aims to analyse and discuss the various problems faced by the LBC. The outcomes of this analysis can be applied to further academic purposes as well as government references in policy making.

Loo-See Beh is Associate Professor at the Department of Administrative Studies and Politics of the Faculty of Economics and Administration, University of Malaya. Her research interests include public administration, human resource management and socio-political economy. Email: lucybeh@um.edu.my 


\section{ACKNOWLEDGEMENTS}

I gratefully acknowledge the constructive comments and invaluable feedback of the editors and two anonymous reviewers. The fieldwork in Wuxi County, Chongqing would not have been possible without the extensive support of Yao Ye, field researcher and MPA graduate. I am also very grateful to all the participants in this research.

\section{NOTES}

1 More specifically, there are 350,000 LBC in Romania, 110,000 in Moldova, 9,500 in Lithuania, 100,000 in Poland and approximately 8,000 in Latvia (Azzini 2011). Most of the LBC in Moldova are children 10 to 14 years old. About 177,000 of the LBC are between 0-18 years old with both parents migrated overseas (UNICEF 2005).

2 Chongqing Daily, 2010 'Give Left-behind Children a Happy Childhood', 7 May 2010.

3 Chongqing Municipal Bureau of Statistics, 2010

4 Chongqing Municipal Bureau of Statistics, 2010.

5 Chongqing Women's Federation 2009. 'Research Report on Rural Left-behind Children in Chongqing'. Available at: http://news.cn6154.com/focus/200903/ t20090330_39814.html

$6 \mathrm{CNN}$ report by April Ma, 'China raises a generation of left-behind children'. Available at: http://edition.cnn.com/2014/02/04/world/asia/china-children-left-behind/ - 5 February 2014 (accessed 7 August 2014).

\section{REFERENCES}

All-China Women's Federation (ACWF) 2008. 'Research Report on Rural Left-behind Children in China'. Available at: http://www.women.org.cn/allnews/02/1985. html (Accessed 11 November 2010).

All-China Women's Federation (ACWF) 2009. 'Thinking on the Social Problems of Rural LBC'. Available at: http://www.women.org.cn/allnews/02/2754.html.

Azzini, C. 2011. 'Brussels Conference Children Left-Behind'. Available at: http:/ / www. childrenleftbehind.eu/countries-of-origin.

Chan A. 2009. 'Paying the Price for Economic Development: The Children of Migrant Workers in China'. China Labour Bulletin Special Report, edited by Geoffrey Crothall, HongKong: CLB. Available at http://www.clb.org.hk/en/files/share/File/research_reports/Children_of_Migrant_Workers.pdf.

China Association of Mayors 2005. China's Urban Development Report (2003-2004). Beijing: Publishing House of Electronics Industry. Available at: http://www.citieschina.org/en/index.php/Report/reportlist.

Chinese Academy of Social Sciences Urban Development and Environmental Research Institute 2010. Annual Report on Urban Development of China, No. 3. Available at: http://www.chinapop.gov.cn/xwzx/rkxw/201007/t20100730_215038.html.

Chongqing Municipal Bureau of Statistics 2010. Chongqing Statistical Yearbook 2010. Chongqing: China Statistic Press.

Chongqing Municipal Bureau of Statistics 2011. Chongqing Statistical Yearbook 2011. Retrieved from http://www.cqtj.gov.cn/tjnj/2011/menu.htm.

Chongqing Municipal Bureau of Statistics 2012. 'Data Communique of the $1 \%$ of 
Population Sampling Survey in Chongqing'. Available at: http://www.cqtj.gov. $\mathrm{cn} / \mathrm{html} / \mathrm{tjsj} / \mathrm{tjgb} / 12 / 02 / 5842 . \mathrm{html}$.

Chongqing Women's Federation 2009. 'Research Report on Rural Left-behind Children in Chongqing'. Available at: http://news.cn6154.com/focus/200903/t20090330_ 39814.html.

Dillon M. 2009. Contemporary China: An Introduction. New York: Routledge.

Ding K.X. 2009. The Rural Left-behind Children Drop Out Status and Countermeasure Analysis After the Implementation of the Compulsory Education Policy in Western China. Educational Measurement and Evaluation. Vol. 3. Available at: http:/ /d.wanfangdata. com.cn/Periodical_jyclypj-ll200903011.aspx.

Duan C.R., and L.L. Wu 2009. 'The Status Quo of Rural Left-behind-Children in China and Its Analysis'. Journal of Chongqing Technology and Business University Social Sciences 26 (1): 24-30.

Duan C.R., and K. Yang 2008. 'The Left-behind Children in Rural China'. Population Research Journal 32 (3): 15-25.

Duan C.R., and F.L. Zhou 2005. 'Research on the States of Left-behind Children'. Population Research 29 (1): 29-36.

Duan C.R., and F.L. Zhou 2006. 'General Research Description of Left-behind Children'. Population Research Journal 3: 60-66.

Fan, P. 2008. 'Chinese Farmer Development Report'. China Collective Economy Journal 2 (10). Available at: http://www.qikan.com.cn/Article/ccez/ccez200810/ ccez20081002-1.html.

Fan S.G, Xing N. \& Cheng Z.G. 2010. The West of China. Research on Public Policy and Rural Poverty. Beijing: Science Press

Fu Q.Y. \& Liu X.Y. 2008. Integrate Urban and Rural: Pay Attention to the Rural Leftbehind Children. Journal of Hubei University of Economics: Humanities and Social Science, 5 (7): 24-25.

Hall, K. 2010. 'Migrant Mothers and Mobile Children-New Possibilities for Exploring Child Poverty Dynamics in South Africa. Children's Institute. University of Cape Town. Available at: http://sds.ukzn.ac.za/files/migrant\%20mothers.PDF.

Liu, Y., and C.F. Zhou 2008. 'The Rural Labor Force Non-agricultural Employment Impact on the Rural Economy-Case Study on the LiZhuang Village of Jiangsu Province'. Nanjing Social Science Journal 11: 124-131.

Ma, S.Z. 2010. 'China's Left Behind Children Often Suffer Health Consequences'. Canadian Medical Association Journal 182 (16): E731-E732.

Ministry of Education Development and Planning 2009. 'Thematic Analysis of the Report on the Migrant Children and Left-behind Children's Education Status'. Available at: http:/ / www.cnsaes.org/homepage/Upfile/2010612/2010061210362299.pdf.

Ministry of Public Security 2008. 'Circular of the Ministry of Public Security on Handling the Work of Left-behind Children'. Available at: http://xxgk.yichun.gov. cn/DiGi/2008-03/30/20080330232907068.doc.

National Bureau of Statistics of the People's Republic of China (NBS) 1999. China Labour Statistical Yearbook 1999. Beijing: China Statistical Press.

National Bureau of Statistics of the People's Republic of China (NBS) 2009. China Statistical Yearbook 2009. Beijing: China Statistical Press.

National Bureau of Statistics of the People's Republic of China (NBS) 2011. China Statistical Yearbook 2011. Beijing: China Statistical Press. Available at: http:/ / www.cqtj. gov.cn/tjnj/2011/menu.htm (accessed 1 February/ 2011).

National Bureau of Statistics (NBS) 2014. 'Statistical Communiqué of the People's Republic of China on the 2013 National Economic and Social Development'. Available at: http://www.stats.gov.cn/english/PressRelease/201402/t20140224_515103.html. 
National Population and Family Planning Commission of the Floating Population Management Division. 2010. 'Report on China's Migrant Population Development'. Beijing: China's Population Press.

Pan, J.H., F.R. Niu, and H.K. Wei 2009. Blue Book of Cities in China - Annual Report of Urban Development of China No. 2, June. Beijing: Social Science Academic Press.

Richburg, K.B. 2010. 'China's "Hukou” System Deemed Outdated as Way of Controlling Access to Services'. Available at: http:/ / www.washingtonpost.com/wp-dyn/content/article/2010/08/14/AR2010081402009.html.

United Nations Office of the High Commissioner for Human Rights 1990. 'Convention on the Rights of the Child'. Available at: http://www.ohchr.org/en/professionalinterest/pages/crc.aspx.

United Nations International Children's Emergency Fund (UNICEF) 2010. 'The Children Left Behind: A league table of inequality in child well-being in the world's rich countries'. Innocenti Report Card 9. Florence: UNICEF Innocenti Research Centre.

UNICEF 2005. Children, Youth and Migration. Available at: http:/ / www.un.org/esa/ population/migration/turin/Turin_Statements/UNICEF.pdf.

Wang, X.H., and J.P. Hu 2011. 'Problems of Left-behind Children Research Paradigm and Extension'. Education Research Monthly. Available at: http://www.cnier. ac.cn/snxx/wenxian/snxx_20111209152329_13138.html.

Wang, H.N. 2009. 'Predicament and the Outlet: A Reflection on the Rural Left-behind Children of Chongqing'. Journal of Yangtze Normal University 25 (3): 148-151.

$\mathrm{Wu}$, Y.M. 2010. 'Analysis on the construction of Chongqing's rural LBC education system'. Youth Explore Journal. Available at: http://www.cnier.ac.cn/snxx/wenxian/snxx_20101223084118_11271.html.

Xiang, B. 2007. 'How far are the left behind left behind? A preliminary study in rural China'. Population, Space and Place 13: 179-191.

Ye, J.Z., and L.Pan 2011. 'Differential Childhoods: Children Left Behind in Rural China'. Journal of Peasant Studies 38 (2): 355-377.

Yeoh, B.S.A., and T. Lam 2006. 'The Costs of $\operatorname{Im}(m o b i l i t y):$ Children Left Behind and Children Who Migrate with a Parent'. Available at: http:/ / www.unescap.org/esid/ gad/Events/RegSem22-24Nov06/Papers/Brenda Yeoh.pdf.

Zhang, H.L., and S.F. Song 2003. 'Rural-urban Migration and Urbanization in China: Evidence from Time-series and Cross-section Analyses'. China Economic Review 14: 386-400.

Zhang, K.H., and S.F. Song 2004. 'Migration and Urbanization'. In Urbanization and Social Welfare in China, edited by Aimin Chen, Gordon G. Liu and Kevin H. Zhang. Burlington, VT: Ashgate.

Zhang, W.T. 2010. 'The Present Situation and the Countermeasures of Left-behind Children's Education'. Journal of Puyang Vocational and Technical College 23 (2): 106-108.

Zhao, F.C. 2009. 'A Study on the Problems in Left-behind Children in Rural Areas'. Available at: http://www.doc88.com/p-206167726357.html. 